\title{
Pengaruh Model Discovery Learning dalam Kemampuan Berpikir Kritis dan Cognitif Mahasiswa Program Studi Sistem Informasi
}

\author{
Wilda Susanti ${ }^{1}$,Darmanta Sukrianto ${ }^{2}$, Dochi Ramadhani ${ }^{3}$ \\ ${ }^{1}$ Program Studi Teknik Informatika, Sekolah Tinggi Ilmu Komputer Pelita Indonesia \\ ${ }^{2}$ Amik Mahaputra Riau \\ 3 Programstudi Pendidikan Teknologi Informasi dan Komputer IKIP PGRI Pontianak \\ wilda@lecturer.pelitaindonesia.ac.id, darmanta@amikmahaputra.ac.id, emaildochi@gmail.com
}

\begin{abstract}
Abstrak- Penelitian ini bertujuan untuk melihat pengaruh model pembelajaran penemuan terhadap kemampuan berpikir kritis dan cogniftif mahasiswa pada kemampuan memecahkan masalah pemrograman. Penelitian ini menggunakan metode quasi experiment dengan dua kelompok desain prestest dan postest. Subjek yang digunakan yaitu mahasiswa Sistem Informasi kelas pagi sebagai kelas percobaan dan kelas malam sebagai kelas kontrol angkatan 2018/2019 sebanyak 41 mahasiswa. Pengumpulan data menggunakan teknik soal tes esai kemampuan berpikir kritis dan kognitif. Analisis data menggunakan uji t. Hasil dari analis di didapat secara signifikan berbeda. Berdasarkan hasil tersebut dapat disimpulkan bahwa terdapat perbedaan dalam berpikir kritis dan kemampuan kognitif mahassiswa di kelas yang diajarkan dengan pembelajaran konvensional dan kelas yang diajarkan denga model pembelajaran penemuan. Sehingga didapatkan hasil kemampuang berpikiri kritis dan kemampuan cognitif mahsiswa dengan model pembelajaran penemuan menghasilkan signifikan yang sangat berbeda dengan hasil lebih baik dari kelas dengan dengan belajar konvensional.
\end{abstract}

Kata Kunci : Model Pembelajaran Penemuan, Berpikir kritis, Kemampuan Kognitif

\begin{abstract}
This study aims to look at the effect of discovery learning models on students' critical and cognitive thinking abilities on the ability to solve programming problems. This study used a quasi-experimental method by doing pretest and posttest design. The subjects used were morning class students as the experimental class and the evening class as the control class 2018/2019 with 41 students. The data collection technique is essay test questions critical thinking skills. Data analysis is using $t$ test. The result of data analysis has different significant. Based on these results, it can be concluded that there is a diference in critical thinking and students' congitive ability in the control class and in the experiment class. However, the results obtained by students' critical and cognitive thinking with a discovery learning model is better than control class.
\end{abstract}

Keywords : Discovery learning,Model, Cognitve Abillity, Critical Thinking

This is an open access article distributed under the Creative Commons 4.0 Attribution License

\section{Pendahuluan}

Pada era revolusi industri 4.0 ini diperlukan generasi yang inovatif yang mendorong mahasiswa belajar mandiri dan bisa terlibat secara aktif dan kreatif dalam pembelajaran. Penggunaan model pembelajaran tentunya harus mampu melibatkan dan mengarahkan mahasiswa untuk aktif terlibat didalam kelas. Peran mahasiswa dalam pembelajaran memberikan konsep kepada mahasiswa untuk dapat memberikan wawasan sebagai pemikir kritis sehingga mahasiswa dapat mengembangkan dan mengontrol pembelajaran sendiri [1]. Pembelajaran aktif terbukti efektif untuk semua disiplin ilmu dan membentuk pembentukan sikap [2] [3].

Kemampuan berpikir kritis mejadikan mahasiwa memiliki kemampuan kognitif yang melibatkan kemampuan afektif dan psikometrik berupa metakognisi dan ketrampilan proses [4]. Berkenaan dengan apa yang dipikirkannya, apa 
yang dikerjakannya terkait dengan tugas yang diberikan. Menurut [5] mahasiswa yang dilatih untuk menggunakan strategi kognitif cenderung tampil lebih baik dalam evaluasi dan sedikit melakukan kesalahan.

Pemrograman komputer memainkan peranan penting dalam disiplin pendidikan komputer. Keahlian yang memerlukan kemampuan berpikir kritis dalam pembelajaran. ini merupakan pengetahuan untuk mempermudah pemahaman alur kerja suatu proses pemrograman berupa coding program yang berisikan tahapan dalam menyelesaikan suatu permasalahan dalam pemrograman. Beberapa konsep pemrograman sulit untuk diserap oleh mahasiswa [6]. Pemrograman dikenal karena kompleksitas sehingga banyak mahasiswa memiliki kesulitan memperoleh kompetensi yang di perlukan [7][8]. Pemrograman komputer membutuhkan pemikiran abstrak, berpikir logis dan ketrampilan dalam coding pemograman. Memahami kesalahan pemrograman mahasiswa sangatlah penting dalam mengindetifikasi kesalahan dalam pemrograman sesuai dengan instruksi. Untuk itu dosen harus memiliki strategi dalam pembelajaran[9]. Mereka membutuhkan dukungan instruksional untuk menguasai bagaimana merencanakan solusi sehingga program dapat dijalankan sesuai dengan kasus yang diberikan [10]. Perubahan tingkah laku, mulai dari pengetahuan, adanya pemahaman sikap dan terbentuknya keterampilan mahasiswa merupakan hasil belajar yang diperoleh oleh mahasiswa dari hasil belajar tersebut. Dimana peserta didik bertanggung jawab atas kemajuan mereka sendiri [11].

Model pembelajaran penemuan merupakan pembelajaran yang mengkonstruksi mahasiswa untuk belajar aktif [12] menuntut mahasiswa terlibat langsung dalam proses kegiatan belajar mengajar. Model pembelajaran penemuan ini merupakan suatu model pembelajaran yang menitik beratkan pada aktifitas belajar [13], Dosen berusaha membelajarkan mahasiswa untuk mengetahui masalah yang ada serta bisa merumuskan masalah dan mampu mencari solusi serta menguji jawaban sementara atas permasalahan yang terjadi dengan melakukan penyidikan atau pengujian yang pada akhirnya mahasiswa dapat memutuskan dan menyimpulkan hasil dari permasalahan tersebut.

Pengujian yang dilakukan pada mahsiswa, hasil nilai yang dilakukan oleh beberapa dosen pada mahasiswa Sistem Informasi semester genap
2018/2019 dengan jumlah mahasiswa 41 orang didapat nilai yang sangat variatif. Nilai rendah $(0-$ 54) sebanyak 3,03 \%, nilai cukup (55-64) $28,78 \%$, nilai memuaskan(65-79) 39,39\% dan nilai sangat memuaskan(80-100) 28,,78 \%. Artinya masih kurang $30 \%$ nilai mahasiswa sangat memuaskan, padahal sesuai dengan kurikulum, mahsiswa semester dua program studi Sistem Informasi sudah dibekali dengan matakuliah konsep dan pemrograman dasar. Namun dalam pembelajaran dikelas masih ada kelemahan dalam proses pembelajaran. Mahaiswa tidak didorong untuk menemukan pengetahuan sendiri, tapi masih didorong untuk mengingat apa yang telah diberikan. Akibatnya pada saat semester tiga terjadi kelemahan dalam tingkat program lanjut. Alur logika mahasiswa masih lemah untuk menjawab sebuah permasalahan. Kesalahan nyaris tidak terkait dengan fitur program tapi dengan algoritma dan alur program untuk strategi pemecahan masalah. Dengan demikian mengidentifikasi kesalahpahaman diamati dalam proses pemecahan masalah akan bermanfaat untuk menentukan model pembelajaran yang digunakan.

Mahasiswa Sistem Informasi dari hasil pengamatan masih lemah dalam kemampuan penyelesaian masalah. Hal ini terlihat dari matakuliah pemrograman dasar. Ketika dihadapkan pada masalah baru, apalagi studi kasus dengan banyak kondisi, mahasiswa sering kebingungan bagaimana cara menyelesaiannya. Kesalahan dalam pembuatan program komputer akibat mahasiswa tidak dilatih dalam logika pembuatan algorima. Hal ini menyebabkan mahasiswa kesulitan dalam menuangkan konsep alur sebuah program. Adakalanya mahasiswa lebih senang langsung melakukan psecoude code di pemrograman. Ketika terjadi kesalahan program mahasiswa kebingungan melakukan analisis karena mereka sebelumnya mengabaikan alur dari sebuah program [14].

Lemahnya alur logika yang dimiliki oleh mahasiswa ini tentu akan berpengaruh terhadap matakuliah yang lain terutama tingkat pemrograman lanjut. Pentingnya interaksi sosial antara mahasiswa dengan seseorang yang lebih terampil dalam tugas untuk mencapai tujuan belajar. Pemanfaatan pengalaman belajar mahasiswa sebelumnya diperlukan untuk membangun pengetahuan yang ada. Mereka akan menemukan makna dalam seluruh proses pembelajaran, bukan hanya di kelas pemrograman [15]. 
Model pembelajaran penemuan adalah serangkaian kegiatan dimana proses pembelajaran yang terjadi bila pelajar tidak disajikan dengan pelajaran dalam bentuk finalnya, mahasiwa harus mandiri dengan hanya materi yang disediakan [16] . Mahasiswa menemukan jawaban sendiri sehingga melatih untuk berpikir krits dan mampu melakukan analisis. Pembelajaran penemuan adalah untuk memberikan pelajaran untuk menangani masalah yang dihadapi untuk dapat memecahkan permasalahan dalam pemrograman. Dimana tujuan utama dari model discovery learning adalah kolaborasi mahasiswa dalam kegiatan belajar maksimal serta keyakinan tentang apa yang ditemukan selama proses pembelajaran [17].

Tahapan model pembelajaran penemuan sebagai berikut [18], (1) dosen menyajikan situasi problematik dan menjelaskan kepada mahsiswa untuk mendorong cara berpikir kritis mahasiswa dan memberikan stimulus sehingga mahasiswa tertarik dalam menuangkan logikanya. (2 Pengumpulan data dan verifikasi mengenai suatu informasi yang dilihat dan dialami (situasi problematik) (3) Pengumpulan data dan eksperimentasi, mahasiswa di perkenalkan dengan elemen baru dengan memberikan peluang dengan situasi yang berbeda (4) Dosen memformulasikan data. (5) membuktikan problematik tersebut dengan melakukan pengujian dengan program. (6) Dosen bersama mahasiswa menarik kesimpulan yang ditetapkan untuk dijadikan prinsip untuk masalah kasus yang sama. Sehingga pelaksaan pembelajaran pada penelitian ini dilaksanakan dalam 6 sintak yaitu (1) stimulus (2) identifikasi masalah (3) pengumpulan data (4) pengolahan data (5) verifikasi data (6) generalisasi/ kesimpulan. Dalam penemuan penerapan model pembelajaran rasa ingin tahu mahasiswa akan muncul. Pengetahuan siswa lebih berkembang dan bermakna menyebabkan pembentukan sikap kritis dan cognitife mahasiwa [19].

Salah satu masalah yang dihadapi dalam pemrograman mengajar adalah sikap negatif dari siswa yang mengangap pemrograman sulit karena membutuhkan ketrampilan berpikir tingkat tinggi seperti pemecahan masalah dan pemikirian logis [20]. Berpikir kritis atau kemampuan untuk terlibat dalam tujuan merupakan sebagai ketrampilan penting untuk pengetahuan [21]. Memiliki kejelasan, relevansi, kecukupan dan koherensi akan terpenuhi apabila kemampuan berpikir kritis menjadi suatu kegiatan yang bisa dilakukan dengan baik.

Penelitian yang dilakukan pada peneliti sebelumnya [22] model pembelajaran penemuan dapat mengurangi kesalahpahaman siswa dan meningkatkan efektivitas tapi hasil uji coba masih kurang tepat pada sintak dalam penemuan belajar yang hanya menganalisis kesalahpahman dalam pembelajaran. Begitu juga eneliti [23] menyebutkan model pembelajaran penemuan dengan pendekatan pembelajaran ilmiah bisa meningkatkan kebutuhan dan ketrampilan berpikir kritis siswa tapi efektifitas masih tergantung pada pendagogi pembelajaran.

\section{METODA}

\section{A. Model Penelitian Penemuan}

Penemuan belajar adalah serangkaian kegiatan aktivitas mahasiswa dalam pembelajaran dari kemampuan untuk menemukan serta menyelidiki sehingga terstrutur, kritis dan masuk akal artinya mahasiswa dapat menemukan pengetahuan mereka sendiri, sikap dan ketramapilan sebagai manifestasi dari perilaku yang berubah. Belajar dengan model penemuan mahasiswa dapat belajar untuk berpikir dan mencoba untuk memecahkan masalah,melakukan analisis sendiri, masalah yang dihadapi kemudian dapat diterapkan. Model pembelajaran penemuan melatih critical thingking mahasiswa menjadikan mahasiswa mudah menguasai materi. Adapun Enam Langkah pada model pembelajaran penemuan ini sesuai pendapat Jerome S. Bruner yang meliputi pemberian rangsangan atau stimulasi, melakukan identifikasi masalah, pengumpulan data, pengolahan data, verifikasi dan generalisasi, hal ini akan mampu mengarahkan mahasiswa untuk kemampuan critical thingking [24].

\section{B. Kemampuan Berpikir Kritis}

Kemampuan berpikir kritis adalah salah satu dari kemampuan berpikir tingkat tinggi, yang mampu mengarahkan mahasiswa untuk menyelesaikan problem solving sehingga tingkat berpikir kritis dalam meyelesaikan masalah didalam kelas, tidak hanya untuk memecahkan masalah, tetap juga mampu memberikan alasan yang masuk akal pada solusi yang diberikan, karena pada dasarnya berpikir merupakan kegiatan yang dilakukan untuk mencapai hasil akhir. Proses kognitif untuk memperoleh pengetahuan adalah kemampuan berpikir 
mahasiswa untuk dapat memperoleh pengetahuan melalui pengujian dan kebenaran ilmiah [25]. Menurut [26] model pembelajaran penemuan mencerminkan proses berpikir kritis dan sarana untuk menghadirkan kemampuan kognitif peserta didik.

\section{Kemampuan Kognitif}

Kognitif berhubungan kognisi. Kognisi adalah bagaimana memperoleh pengetahuan ( terdapat kesadaran, perasaan dan lain-lain) atau mendapatkan pengaalaman sendiri dari upaya pengetahuan ini. Menurut Bloom kognitif adalah ranah yang memperhatikan pengembagan kemampuan dan ketrampilan intelektual [27]. Menurut Jean Peaget dalam penelitian [28] mengemukan pada tahap tertentu kemampuan kognitif setiap manusia dimulai dari lahir hingga dewasa pada tahap tertentu tidak sama untuk setiap orang.

\section{Populasi Sampel}

Sampel dari percobaan ini adalah mahasiswa semester III program studi Sistem Informasi. Penelitian ini mengambil dua kelas contoh dengan perlakukan yang berbeda. Dikelas pertama kelas uji coba yaitu kelas pagi diterapkan dengan model pembelajaran penemuan dan kelas kontrol dengan pembelajaran konvensional. Desain penelitian ini adalah dua kelompok desaain pretest-postest. Desain penelitian berikut ini dapat dilihat pada tabel 1.

Tabel 1. Desain penelitian

\begin{tabular}{|l|c|c|c|c|}
\hline \multicolumn{1}{|c|}{ Kelas } & $\begin{array}{c}\text { Jumlah } \\
\text { Mahasiswa }\end{array}$ & Prestest & Treatment & Postest \\
\hline $\begin{array}{l}\text { Percobaan } \\
\text { kelas ( S- } \\
\text { SI) }\end{array}$ & 19 & Y1 & $\mathrm{X} 1$ & $\mathrm{Y} 2$ \\
\hline $\begin{array}{l}\text { Kontrol } \\
\text { (M-SI) }\end{array}$ & 22 & $\mathrm{Y} 1$ & $\mathrm{X} 2$ & $\mathrm{Y} 2$ \\
\hline
\end{tabular}

Informasi :

X1 : Belajar menggunakan model pembelajaran penemuan menggunakan materi menerapkan algortirma dan flowchart dalam menyelesaikan masalah pemrograman

$\mathrm{X} 2$ : Belajar dengan pembelajaran konvensional pada materi menerapkan algoritma dan flowchart dalam menyelesaikan masalah pemrograman.
Y1 : Prestest diberikan sebelum treatmen di kelas Y2 : Pascauji acak diberikan setelah treatmen di kelas dan kontrol eksperimen kelas

Teknik pengumpulan data adalah langkah utama dalam penelitian, karena tujuan dari uji coba ini adalah untuk menghasilkan data percobaan yang digunakan untuk memperoleh data dalam penelitian dalam bentuk pemikiran kritis dan kemampuan kognitif. Kedua instrumen ini mengabdosi dari peneliti, yang telah mampu digunakan untuk menentukan hasil belajar mahasiswa dan kepercayaaan diri mahasiswa.

Pengumpulan data dilakukan dalam dua tahap, langkah pertama adalah mengumpulkan data tentang kemampuan data tentang kemampuan pemecahan masalah dan tahap kedua mengumpulkan data tentang kemampuan berpikir kritis. Data yang diperoleh dalam uji coba ini dianalisis secara deskriptif dan inferensial. Inferensial analisis statistik, untuk menguji hipotesis. Sebelum pengujian hipotesis diuji persyaratan normalitas uji data penelitian dengan teknik liliefors, maka dilanjutkan dengan uji homogenitas. Hasil uji homogenitas 1,90>0,05, maka dinyatakan homogeny

\section{HASIL DAN PEMBAHASAN}

Data diperoleh setelah pretest dan postest dapat dilihat pada tabel 2. Pretest dilakukan sebelum uji coba perlakuan dan postest dilakukan setelah perlakukan discovery learning baik dari kelas eksperimen maupuan kelas kontrol. Soal yang diberikan adalah sama yaitu soal essay.

Tabel 2. Ringkasan prestest-postest berpikir kritis dan kemampuan kognitif dari kelas kontrol dan kelas eksperimen

\begin{tabular}{|l|l|l|l|}
\hline Variabel tak bebas & Kelas & $\begin{array}{l}\text { Mean } \\
\text { Prestest }\end{array}$ & $\begin{array}{l}\text { Mean } \\
\text { Postest }\end{array}$ \\
\hline Berpikir Kritis & Kontrol & 16,26 & 73,58 \\
\cline { 2 - 4 } & Percobaan & 15,41 & 76,96 \\
\hline $\begin{array}{l}\text { Kemampuan } \\
\text { Kognitif }\end{array}$ & Kontrol & 18,18 & 72,72 \\
\cline { 2 - 4 } & Percobaan & 18,71 & 74,85 \\
\hline
\end{tabular}

Tabel 3. Posttest-t Posttest Kemampuan berpikir kritis

\begin{tabular}{|l|l|l|l|l|} 
'Post test & $\mathrm{t}_{\text {counted }}$ & $\mathrm{t}_{\text {tabel }}$ & Sig & Information \\
\hline
\end{tabular}




\begin{tabular}{|c|c|c|c|c|}
\hline Persamaan Uji & & & & \\
\hline Test-t & 1,776 & 1,697 & 0,028 & $\begin{array}{c}\text { Secara } \\
\text { signifikan } \\
\text { berbeda }\end{array}$ \\
\hline
\end{tabular}

Berdasarkan tabel 3, hasil ini menunjukkan bahwa hasil indikasi bahwa $\mathrm{t}_{\text {counted }}>\mathrm{t}_{\text {table }}$ dan nilai sig lebih kecil dari 0,05. Artinya secara signifikan berbeda. Hasil tersebut dapat disimpulkan bahwa terdapat perbedaan cara berpikir mahasiswa kelas yang diajarkan dengan pembelajaran penemuan dengan kelas konvensioanl, dimana mahasiwa berpikir kritis dikelas uji coba lebih berkembang dan mendapatkan nilai yang lebih baik dalam pemecahan masalah pemrograman

Tabel 4. Test-t Postest cognitive ability

\begin{tabular}{|c|c|c|c|c|}
\hline $\begin{array}{c}\text { Post test } \\
\text { persamaan uji }\end{array}$ & $\mathrm{t}_{\text {counted }}$ & $\mathrm{t}_{\text {tabel }}$ & Sig & Information \\
\hline Test-t & 1,822 & 1,697 & 0,076 & $\begin{array}{c}\text { Secara signifikan } \\
\text { berbeda }\end{array}$ \\
\hline
\end{tabular}

Berdasarkan tabel 4, hasil ini menunjukkan bahwa tcounted >ttable hasil uji statistik didapatkan nilai secara signifikan berbeda dimana nilai sig lebih besar dari 0,05 . Berdasarkan hasil tersebut dapat disimpulkan ada perbedaan kemampuan kognitif mahasiswa kelas kontrol dan kelas eksperiment dimana kelas yang diajarkan dengan pembelajaran konvensional dan kelas yang di ajarkan dengan model pembelajaran penemuan, dengan hasil yang diperoleh pemikiran kognitif kelas dengan penemuan model pembelajaran lebih baik dari kelas dengan pembelaran konvensional. Dalam hal kemampuan kognitif mahasiswa dalam hal berpikir secara logis dan berpikir secara prosedural.

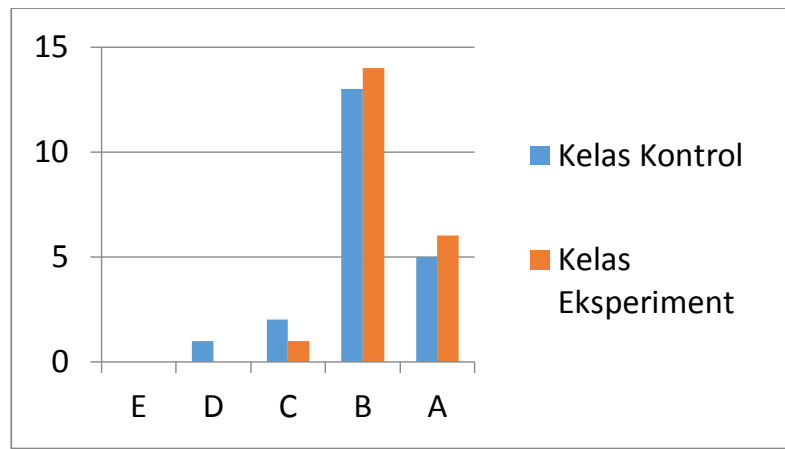

Gambar 1. Keterampilan berpikir krits mahasiswa lebih baik dari uji coba dua kelas
Dari gambar 1 terlihat penyebab kemampuan berpikir kritis mahasiswa di kelas uji coba dua kelas yaitu kelas menggunakan model penemuan lebih baik daripada kelas kontrol karena kegiatan belajar penemuan dapat mendukung mahasiswa dalam menemukan sesuatu dari masalah yang diberikan oleh dosen. Masalah yang disajikan dijawab oleh mahasiswa berupa algoritma dan alur program berupa flowchart serta hasil akhir dibuktikan dengan program. Program merupakan hasil akhir dari pembuktian untuk mendapatkan pengetahuan dengan menggunakan Pseu Code, , merumuskan sintak, membuat hipotesis dari hasil logika, mengumpulkan data dan menyimpulkan dengan cara melakukan pengujian. Kegiatan ini kemampuan berpikir kritis mahasiswa menjadi meningkat. Kemampuan berpikir kritis ini tidak diperoleh dari cara menghafal. Hal yang sama disampaikan model penemuan belajar memiliki positif yang signifikan berpengaruh pada prestasi akademik mahasiswa.

Kemampuan kedua yang menyebabkan kemampuan berpikir kritis mahasiswa di kelas uji coba dua kelas adalah kelas dengan pembelajaran penemuan lebih baik dari kelas kontrol karena mahasiswa dapat dilatih berpikir logis. Berpikir logis dapat diperoleh siswa ketika memberikan argumen yang logis untuk menentukan kesimpulan. Logis dalam menuangkan alur pemikiran menggunakan algoritma dan dapat digambarkan alur berupa bagan. Sehingga pemahaman yang benar dari konsep dapat meningkatkan hasil belajar.

Faktor ketiga yang menyebabkan kemampuan berpikir kritis mahasiswa di dua kelas uji coba yaitu kelas dengna pembelajaran penemuan lebih baik dari pada kelas kontrol karena mahasiswa penemuan belajar dilatih berpikir sistematis sehingga pemahaman dan analisis mahasiswa optimal. Berpikir sistematis adalah mahasiswa pola metode ilmiah dapat diikuti, mulai dari pengamatan analis permasalahan, mengajukan pertanyaan berdasarkan permasalahan yang terjadi. Pertanyaan yang di ajukan oleh dosen akan merangsang mahasiswa mengajukan pertanyaan berdasarkan pengamatan dan analisis yang dilakukan. Perumusan pertanyaan yang diajukan oleh mahasiswa akan merangsang kemampuan berpikiri setiap rumuskan masalah. Dengan rumuskan masalahyang didapat akan pengetahuan awal mereka jadi optimal dengan 
mengingat konsep-konsep yang berhubungan dengan kegiatan yang dilakukan.

Berbeda dengan kelas konvensional, dosen hanya menyajikan informasi langkah demi langkah. Mahasiswa hanya memperhatikan dan menerima apa saja yang telah disampaikan dosen. Sehingga pemikiran mahasiswa tidak berkembang dengan baik. Mahasiwa hanya menerima apa saja yang disampaikan oleh dosen, tetapi mahasiswa tidak mengerti untuk apa konsep yang dipelajari. Sehingga kemampuan berpikir kritis mahasiswa belum berjalan dengan optimal, karena dosen dominan didalam kelas, cendrung lebih terpusat. Kelemhan pembelajaran konvensional adalah ketika diberikan permasalahan baru, mahasiswa cendrung menjadi pasif dan menunggu instruksi dari dosen di kelas.

Kemampuan kognitif mahasiswa yang diajar dengan model penemuan lebih baik dari pembelajaran konvensional.terlihat pada gamabar 2.

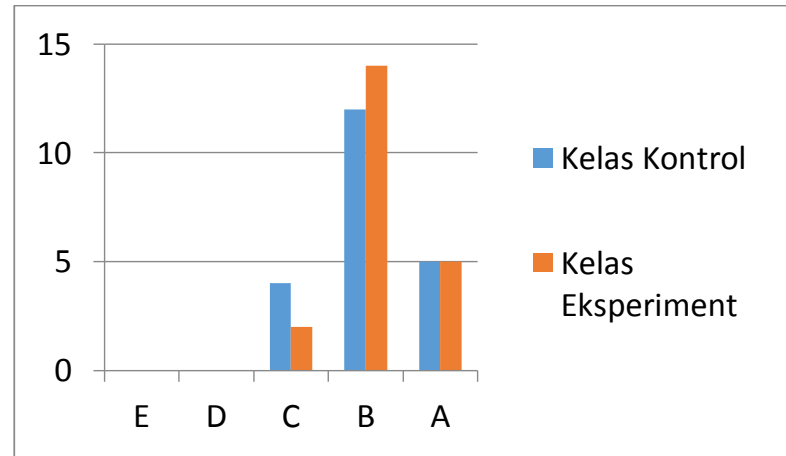

Gambar 2. Kemampuan kognitif mahasiswa yang lebih baik di kelas eksperimen dibandingkan dengan kelas control

Penyebab kemampuan kognitif di kelas eksperimen lebih baik daripada kelas kontrol karena belajar penemuan dapat melibatkan mahasiswa secara aktif. Pembelajaran menjadi berpusat pada siswa untuk menyelidiki masalah yang disajikan pada kelas. Berdasarkan kemampuan kognitif membutuhkan keterlibatan kemampuan afektif dan psikomotorik. Mahasiswa dilatih untuk menjadi terampil dalam memperoleh dan mengolah informasi. Pengetahuan yang diperoleh mahasiswa memahami logika dan alur dari setiap permasalahan yang diberikan karena pembelajaran penemuan mempromosikan rasa ingin tahu mendorong mahasiswa meningkatkan pengetahuan dan mengembangkan ketrampilan [29]. Kegiatan pembelajaran penemuan dapat 58 INVOTEK: Jurnal Inovasi, Vokasional dan Teknologi, Vol. 20 No. 3, memberikan kesempatan kepada mahasiswa untuk menemukan sesuatu melalui eksperimen. Berdasarkan kemampuan kognitif mahasiswa mendapatkan pengetahuan baru atau mengembangkan pengetahuan yang sudah dimiliki.

\section{IV.KESIMPULAN}

Berdasarkan hasil pembahasan dapat disimpulkan bahwa penerapan model discovery learning untuk mahasiswa semester tiga program studi Sistem Informasi yang belajar pemrograman, kemampuan berpikir kritis menjadi lebih baik dari pada pembelajaran secara konvensional. Hal ini dikarenakan kemampuan berpikir kritis mahasiswa jadi berkembang, mahasiswa bisa menemukan pengetahuan nya sendiri, mahasiwa menjadi lebih aktif menjadikan mahasiswa sebagai pusat pembelajaran tidak lagi kepada dosen.

Begitu juga dengan kemampuan kognitif mahasiswa belajar dengan discovery learning menjadi baik dari yang diajarkan secara konvensional ini terlihat dari kemampuan berpikir dalam pemecahan permasalahan dan pengambilan keputusan. Hasil dari pengujian prestest dan postest dari dua kelas, kelas eksperimen dan kelas kelas kontrol setelah menggunakan model penemuan ini diperlukan evaluasi pembelajaran penemuan ini untuk hasil yang lebih baik.

\section{DAfTAR PUSTAKa}

[1] N. K. H. Sayukti, "Integrating self-regulated learning and discovery learning into English lesson plan," SHS Web Conf., vol. 42, p. 00047, 2018.

[2] L. E. Ott, T. S. Carpenter, D. S. Hamilton, and W. R. LaCourse, "Discovery Learning: Development of a Unique Active Learning Environment for Introductory Chemistry," $J$. Scholarsh. Teach. Learn., vol. 18, no. 4, pp. 161-180, 2018.

[3] M. D. Svinicki, "A theoretical foundation for discovery learning.," Am. J. Physiol., vol. 275, no. 6 Pt 2, pp. 4-7, 1998.

[4] H. Suyitno and I. Artikel, "Model Pembelajaran Discovery Learning Dengan Pendekatan Metakognitif Untuk Meningkatkan Metakognisi Dan Kemampuan 
Berpikir Kreatif Matematis," Unnes J. Res. Math. Educ., vol. 4, no. 1, pp. 10-17, 2015.

[5] Y. W. Kwan and A. F. L. Wong, "Effects of the constructivist learning environment on students' critical thinking ability: Cognitive and motivational variables as mediators," Int. J. Educ. Res., vol. 70, pp. 68-79, 2015.

[6] A. Febrian and O. Lawanto, "Do Computer Science Students Understand Their Programming Task?-A Case Study of Solving the Josephus Variant Problem," Int. Educ. Stud., vol. 11, no. 12, p. 26, 2018.

[7] M. S. Gunbatar, "Examination of Undergraduate and Associate Degree Students' Computer Programming Attitude and Self-Efficacy According to Thinking Style, Gender and Experience," Contemp. Educ. Technol., vol. 9, no. 4, pp. 354-373, 2018.

[8] F. Saltan, "The Impact of Online Algorithm Visualization on ICT Students' Achievements in Introduction to Programming Course," J. Educ. Learn., vol. 6, no. 1, p. 184, 2016.

[9] A. W.Susanti, "Analisis Korespondensi Hubungan Strategi Pembelajaran Dengan Hasil Belajar Mahasiswa," vol. 1, 2018.

[10] K. Kwon, "Novice programmerâ $€^{\mathrm{TM}} \mathrm{S}$ misconception of programming reflected on problem-solving plans," Int. J. Comput. Sci. Educ. Sch., vol. 1, no. 4, p. 14, 2017.

[11] E. De Corte, "Improving Higher Education Students' Learning Proficiency by Fostering their Self-regulation Skills," Eur. Rev., vol. 24, no. 2, pp. 264-276, 2016.

[12] N. Saab, W. R. Van Joolingen, and B. H. A. M. Van Hout-wolters, "Communication in Colaborative Discovery Learning," pp. 603621, 2005.

[13] Y. S. Tsamaniarty Hidayah, "Pengembangan Model Pembelajaran Discovery Learning pada Mata Kulliah Perkembangan Kepribadian Mahasiswa AMIK DCC Bandar Lampung," Obor Penmas, vol. 2, no. 2, 2019.

[14] 2018 Irma Ayu Aryani, "MULTIMEDIA PEMBELAJARAN UNTUK ALGORITMA DAN MENGGUNAKAN MODEL PEMBELAJARAN PROBLEM POSING UNTUK MENUNJANG CRITICAL THINKING Universitas Pendidikan Indonesia | repository.upi.edu perpustakaan.upi.edu," 2018.
[15] C. C. Hudson and V. R. Whisler, "Contextual teaching and learning for practitioners," IMSCI 2007 - Int. Multi-Conference Soc. Cybern. Informatics, Proc., vol. 2, no. 4, pp. 228-232, 2007.

[16] S. .G, "Discovery Learning Strategies In English," i-manager's J. English Lang. Teach., vol. 2, no. 1, pp. 57-62, 2012.

[17] T. dkk Martaida, "The Effect of Discovery Learning Model on Student's Critical Thinking and Cognitive Ability in Junior High School," Iosr-Jrme, vol. 7, no. 6, pp. 1$8,2017$.

[18] K. dkk Yuliani, "The development of learning devices based guided discovery model to improve understanding concept and critical thinking mathematically ability of atudents at Islamic Junior High School of Medan," J. Educ. Pract., vol. 6, no. 24, pp. 116-128, 2015.

[19] N. Khasanah, Sajidan, Sutarno, and B. A. Prayitno, "Implementation of discovery learning model with integrated unity of sciences in the develop of critical thinking skills and personal religious beliefs (PRB) of students," Man India, vol. 97, no. 19, pp. 353-361, 2017.

[20] Y. B. İ. R. Çalişma, “A study for determining computer programming students' attitudes towards programming and their programming self-efficacy / Bilgisayar programcilığ ögrencilerinin programlamaya karşı tutum ve programlama öz-yeterliklerinin belirlenmesine yönelik bir çalı," Eğitimde Kuram ve Uygul., vol. 11, no. 1, pp. 51-67, 2014.

[21] P. C. Abrami et al., "Instructional interventions affecting critical thinking skills and dispositions: A stage 1 Meta-Analysis," Rev. Educ. Res., vol. 78, no. 4, pp. 11021134, 2008.

[22] B. Tompo, A. Ahmad, and M. Muris, "The Development of Discovery-Inquiry Learning Model to Reduce the Science Misconceptions of Junior High School Students," vol. 11, no. 12, pp. 5676-5686, 2016.

[23] E. Nurcahyo and L. A. S, "Implementation of Discovery Learning Model with Scientific Learning Approach to Improve Students , Critical Thinking in Learning History," Int. J. Multicult. Multireligious Underst., pp. 106112, 2018.

[24] Y. Nurrohmi, S. Utaya, and D. H. Utomo, 
"Pengaruh Model Pembelajaran Discovery Learning Terhadap Kemampuan Berpikir Kritis Mahasiswa," J. Pendidik., vol. 2, no. 1, pp. 1308-1314, 2017.

[25] A. Setyowati and B. Subali, "KRITIS SISWA SMP KELAS VIII," vol. 7, pp. 8996, 2011.

[26] D. R. Garrison, T. Anderson, and W. Archer, "Critical Thinking, Cognitive Presence, and Computer Conferencing in Distance Education," pp. 1-24.

[27] R. Laferriere, B. Engeler, and A. Rixon, "Addressing Cognitive Challenges in Applying Design Thinking for Opportunity Discovery: Reflections from a Design Thinking Teaching Team," She Ji, vol. 5, no. 4, pp. 383-386, 2019.

[28] F. Ibda, "PERKEMBANGAN KOGNITIF : TEORI JEAN PIAGET," vol. 3, pp. 27-38, 2015.

[29] B. McDonald, "Self Assessment and Discovery Learning.," Online Submiss., vol. 1, no. 868, 2011.

\section{Biodata Penulis}

Penulis adalah Wilda Susanti,M,Kom lahir pada tanggal 8 September 1972, Gelar Sarjana Teknik Informatika di peroleh Tahun 2007 di STMIK-AMIK Riau. Tahun 2008 memperoleh gelar Magister Ilmu Komputer di Univeristas Putra Indonesia YPTK Padang.Staf pengajar di Program Studi Teknik Informatika di Sekolah Tinggi Ilmu Komputer Pelita Indonesia sejak tahun 2008 sampai sekarang. 